ROCZNIKI TEOLOGICZNE

Tom LXVIII, zeszyt 7 - 2021

DOI: https://doi.org/10.18290/rt21687-5

IRYNA SASHKO

\title{
ПОСЛЕДНИЕ ВРЕМЕНА ЭТОГО МИРА \\ В БОГОСЛОВСКОЙ МЫСЛИ \\ ПРЕПОДОБНОГО ИУСТИНА ПОПОВИЧА
}

\author{
THE LAST TIMES OF THIS WORLD IN THEOLOGICAL THOUGHT \\ VENERABLE JUSTIN POPOVICH
}

\begin{abstract}
A b stract. The doctrine of the last times of this world of the Monk Justin Popovich concentrates primarily around the signs announcing the end of the world, which include the preaching of the Gospel to all nations, the conversion of Israel to Christ, the appearance of the Antichrist, a cosmic catastrophe, and also the heavenly sign of the cross on the eve of the Second Coming of the Savior. According to the Monk Justin, the most tragic moment at the end of this world will be the appearance of the Antichrist, in which all evil will reach its apogee. Proceeding from the Holy Scriptures, as well as the works of the Church Fathers, Archimandrite Justin discusses the resurrection of the human body, as well as the anakefalaiosis of everything created under the head of Christ, when only God "will be all in all" (1 Cor. 15:28). For Archimandrite Justin, the greatest gift of the Risen God-Man to human nature is the immortality of body and matter.
\end{abstract}

Keywords: eschatology; Parusia; the Last Judgment; Antichrist; anakefalaiosis; Venerable Justin Popovich.

Учение Преподобного Иустина Поповича (1894-1978) - выдающегося подвижника и исповедника Сербской Православной Церкви, архимандрита, богослова и философа, причисленного в 2010 году к лику святых, иногда сравнивается с учением вселенских учителей и Отцов Церкви, принадлежащих всему миру ${ }^{1}$. Несомненно, преподобный Иустин «оставил после

ИРинА САшко - доктор богословия, доцент Кафедры славянской филологии Хмельницкого национального университета; e-mail: irenasaszko@gmail.com

IRYNA SASHKO - Doctor of Theology, Associate Professor of the Department of Slavic Philology, Khmelnytskyi National University; e-mail: irenasaszko@gmail.com 
себя богатейшее богословское, философское и агиографическое наследие» ${ }^{2}$. Однако, несмотря на это, его богословие нечто несистематично, ведь автор «не столько перечисляет догматы в строго школьном или историческом изложении, сколько пытается передать свое переживание этих догматов, являя их, так сказать, экзистенциальную значимость» ${ }^{3}$. Архимандрит Иустин, излагая истины веры, «обращается скорее к чувствам, нежели к рассудку или разуму» ${ }^{4}$, используя при этом проповеднический тон, полон риторических фигур, повторений, сравнений, метафор или даже неологизмом. Таким образом его учение имеет более пасторальный характер, нежели богословский. Очень четко это можно проследить в его богословских трудах по догматике Православной Церкви ${ }^{5}$, а в частности в его размышлениях о пришествии последних времен и конце света ${ }^{6}$.

\section{1. ЗНАКИ КОНЦА СВЕТА}

Ожидая Второго Пришествия Спасителя, первые христиане взывали «Маранафа! Гряди Господи Иисусе!» (Откр. 22, 20). При этом возносили свои руки в жесте оранты как знак их открытости и тоски по Господу. Ибо Его пришествие обозначало искупление, освобождение и новую жизнь. Со временем, однако, Спаситель мира приобрел черты rex tremendae maiestatis, а встреча с ним была представлена как dies irae, calamitatis et miseriae ${ }^{7}$. В большой мере на это повлияло латинское средневековье. Но также святоотеческая педагогика страха отыграла в этом немалую роль ${ }^{8}$. Ее влияние можно проследить также в учении преподобного Иустина

\footnotetext{
${ }^{1}$ Иеромонах Радованович, иером, „По страницам богословских трудов архимандрита Иустина (Поповича)”, Журнал Московской Патриархии 4(1999): 35. См. Е. Холмогоров, „Преподобный Иустин (Попович)”, Церковность. Православный интернет-альманах 1(1999). (Дата доступа: 10.02.2021: http://www.romanitas.ru/content/popovich/life.htm).

${ }^{2}$ Мефодий Зенковский, „Понятие человеческой личности в сербской богословской мысли ХХ века”, в: Труды Перервинской Духовной Семинарии, ред. В. Чувикин (Москва: Перервинская православная духовная семинария, 2013), 24.

3 „От редакции”, в: Иустин Попович, Догматика Православной Церкви: эсхатология, перевод М.Н. Яценко (Москва: Издательский Совет Русской Православной Церкви, 2005), 3.

${ }^{4}$ Ibidem.

${ }^{5}$ Ibidem; Иустин Попович, Догматика Православной Церкви: пневматология, перевод М.Н. Яценко (Москва: Издательский Совет Русской Православной Церкви, 2007).

${ }^{6}$ См. Попович, Догматика Православной Церкви.

${ }^{7}$ Cм. Tomáš Špidlík, Życie po śmierci. Maranatha, tłum. Patrycja Mikulska (Kraków: Salwator, 2009), 104.

${ }^{8}$ См. ibidem, 104, 112-113.
} 
Поповича. Несмотря на то, что архимандрит Иустин очень любил противопоставлять слово «благовестие» со словом «горьковестие», а его богословские размышления сосредотачивалось на Тайне Воплощения и единства, он все же очень много внимания посвящал грехопадению, злу и разрушению этого мира. Подчеркивая значимость личности Иисуса, отец Иустин - казалось бы - более акцентировал Его справедливость, нежели любовь, прощение и милосердие. По крайней мере, если речь идет о размышлениях преподобного Иустина на тему православной эсхатологии.

Посылаясь на Библейские тексты, архимандрит Иустин Попович утверждает, что в Последний день (гр. hemera eschate) (Ин. 6, 39-40.44), Великий день (гр. hemera megalen) (Деян. 2,20) и Судный день (гр. hemera kriseos) (Мф. 10,15), Христос «окончательно разлучит добро от зла и проведет между ними непроходимую границу», измеряя «все дела человеческие, все мысли человеческие, все желания человеческие, все слова человеческие на сверхчувствительных и точных Богочеловеческих весах правды и любви» ${ }^{9}$. Священное Писание не толкует о том, что же действительно произойдет в Судный день и удерживает молчание относительно его часа, но все же, посылаясь на Евангелие и Отцов Церкви, преподобный Иустин выделяет пять ключевых знамений, которые будут предвещать близость Его пришествия. Первый знак - это, можно сказать, активная миссионерская деятельность Церкви, когда Слово Божье будет провозглашено всем народам и всей твари. И здесь преподобный Иустин вводит антиномию, утверждая, что благодаря Евангельской проповеди, с одной стороны, Благая Весть даст возможность войти в Церковь всем язычникам, с другой же - «многие, узнав об Евангелии, яростно восстанут против него и тем самым покажут, насколько люди влюблены во зло, насколько стали рабами греха и лжи, насколько стали орудием сатанинского зла против вечного Божьего добра» ${ }^{10}$. Поэтому в последний день этого мира всех ожидает справедливый и безжалостной Божий Суд. Вторым знаком Парузии - по мнению архимандрита - будет обращение Израиля ко Христу, и, что интересно, это обращение должен будет совершить «пророк Илья Фесвитянин, который вместе с Енохом придет с Неба во дни Антихриста и будет бороться против него за правду Евангелия Христова» ${ }^{11}$. Третий знак последних времен - это появление Антихриста олицетворение всемирного зла. Теме пришествия Антихриста преподобный

\footnotetext{
9 Попович, Догматика Православной Церкви: эсхатология, 67-68.

${ }^{10}$ Ibidem, 70-71.

${ }^{11}$ Ibidem, 71.
} 
Иустин посвящает очень много места в своей «Догматике», как бы пытаясь предостеречь своих читателей пред его разрушительной силой. Великие потрясения среди людей и в природе, т.е. войны, революции, голод, мор, землетрясения сербский богослов относит к четвертому знамению Парузии. В то время, как пятым и уже последним предсказанием Страшного Суда будет появление на небе крестного знамени, сияющего светлее от солнца. Ссылаясь на св. Иоанна Златоустого, преподобный Иустин утверждает, что крест показывает не только раны Спасителя, но и Его постыдную смерть, которая должна стать выразительным знаком для неверующих ${ }^{12}$.

Для преподобного Иустина Поповича Парузия остается быть тайной, ведомой только самому Богу. Тем не менее, он обращает внимание на то, что «в этот необычный день время перестанет существовать», оно, «какимто таинственным образом утонет в вечности». Другим словами, на смену хронологическому времени наступит время kairos, когда Христос - Альфа и Омега - «будет все во всем» (1 Кор. 15,28). Ибо «Христос - всеединство. Христос - воссоединитель. В Нем, в Богочеловеке, [...] соединяется Бог и человек, небо и земля, ангелы и люди, существа и вещи, атомы и вселенная, всё, что на небе, и всё, что на земле, кроме греха, смерти и диявола» ${ }^{13}$.

\section{2. АНТИХРИСТ И ЕГО ДЕЯТЕЛЬНОСТЬ}

Пришествие Антихриста - тема, которой интересовались уже первые христиане (Дидахе XVI, 3-4 и Послание Варнавы 4,3), а также Отцы Церкви. В древности, исходя из Быт. 49, 16-17, предполагалось, что Антихристом будет псевдо-Мессия, явившийся в Иерусалиме. Так, среди других, считали св. Иероним, св. Ириней Лионский, св. Амвросий и блаженный Августин. Св. Кирилл Александрийский придерживался мысли, что воплощением Антихриста был римский император Нерон (эта идея была возрождена в XVII в.). В свою очередь, в период гонений считалось, что Антихрист является коллективной фигурой, и есть ним целая Римская империя, а в трудном периоде борьбы с исламом черты Антихриста приписывали пророку Мухаммеду. Впрочем, не существует однозначного ответа на вопрос, кем будет Антихрист и когда ожидать его пришествия. Богословие избегает каких-либо аллюзий, подчеркивая эсхатологично-

\footnotetext{
12 Ibidem, 102.

${ }^{13}$ Попович, Догматика Православной Церкви: пневматология, 78.
} 
символический характер библейских высказываний. ${ }^{14}$ Следует также отметить, что, кроме Апостола Иоанна, который об Антихристе говорит прямо, о пришествии псевдо-Христа и псевдо-Пророка вспоминают также синоптические Евангелия (см. Мк. 13, 6.22; Ин. 5,43). Св. Апостол Павел говорит об «человеке греха», «сыне погибели, противящимся и превозносящимся выше всего» (2 Фес. 2,3-8), а Откровение Иоанна Богослова о двух Зверях (Откр. 13,1-18), великой Блуднице (Откр. 17) и Лжепророке $(16,13)$. Если же обратиться к Ветхому Завету, то тут, прежде всего, надо вспомнить пророчества Иезекииля и Даниила. Первый упоминает определенную группу враждебных сил, имеющих определенного представителя в лице правителя Тира (Иез. 28,2), фараона (Иез. 29,3) или же жестокого Гога (Иез. 38,2-9). Второй же перечисляет множество нечестивых сил, олицетворенных в исторической личности Антиоха IV Эпифана ${ }^{15}$.

Как уже упоминалось выше, преподобный Иустин Попович довольно широко рассматривает тему появления Антихриста в истории человечества, называя его «всегрехом» ${ }^{16}$ и «всезлом», т.е. тем, кто «соберет в себе и абсолютизирует все, что когда-либо в любом теле бесновалось или беснуется» ${ }^{17}$. «Он будет гениально и неподражаемо зол»- уверяет преподобный Иустин ${ }^{18}$, но при этом «не будет воплощением дьявола, ибо дьявол не может воплотиться в человека» ${ }^{19}$. Согласно сербскому богослову, Антихрист будет рожден от блуда и примет на себя все действие Сатаны, будет полностью контролируемым Сатаной и ним руководимым. Его ум, сердце, совесть и воля - все будет «мастерской Сатаны». А восседать он будет во всех церквях мира, кроме иерусалимского храма. ${ }^{20}$ Он будет очень коварный. «Логика зла и греха найдет в нем своего мудрейшего апологета. Антихрист будет обладать способностью маскировать зло под мнимое добро, искусно смазывать яд смерти ложным медом бессмертия, художественно покрывать мерзость греха мнимыми чудесами и знамениями, с помощью магии делать греховные наслаждения соблазнительно

\footnotetext{
${ }^{14}$ Jerzy Misiurek, „Antychryst”, в: Encyklopedia Katolicka, red. Feliks Gryglewicz, Romuald Łukaszyk, Zygmunt Sułowski, T. 1 (Lublin: Towarzystwo Naukowe KUL, 1985), 709-710.

${ }^{15}$ Kazimierz Romaniuk, „Antychryst”, в: Encyklopedia Katolicka, т. 1, 708-709. Cp. Béda Rigaux, „Antychryst”, w: Stownik teologii biblijnej, red. Xavier Léon-Dufour, thum. i oprac. Kazimierz Romaniuk (Poznań: Pallotinum, 1994), 52-54; Олександр Мень, Апокаліпсис. Тлумачення Книги Одкровення, перекл. Мирослави Лемик (Львів: Свічадо, 2016), 69-72.

${ }^{16}$ Попович, Догматика Православной Церкви: эсхатология, 93.

${ }^{17}$ Ibidem, 74.

${ }^{18}$ Ibidem.

${ }^{19}$ Ibidem, 75.

${ }^{20}$ Cм. ibidem, 75-76; 94.
} 
привлекательными» и даже превращаться в светлого ангела (см. 2 Кор. $11,14) »^{21}$. Так, как Антихрист провозгласит себя богом, его власть на земле - казалось бы - будет безграничной. Тем не менее, она будет только мнимой, ведь все, что обосновано на лжи не может быть правдивым и долговечным. Антихрист - полная противоположность Богу - лжец. Посему преподобный Иустин называет его антибогом, антигосподом, антиистиной, антиправдой, антилюбовью, антидобром, антижизнью, антибессмертием, античеловеколюбцем и самым кровожадным античеловеком ${ }^{22}$. Цель его появления - ни что другое, как «одьяволичение» человека, создание «дьявололюдей», путем лишения их свободы, ${ }^{23}$ ибо «вершина спасения и обожения - отроичение» человека, т.е. реализация его свободы как любви к Богу, ближнему и всему миру ${ }^{24}$. Таким образом, заданием Антихриста будет разрушение Церкви как таковой, «ибо борьба против Церкви, по сути, - это борьба против Святой Троице на земле (ср. 1 Ин. 2,22-23). Преподобный Иустин не называет конкретной даты появления Антихриста, но уверяет, что это наступит тогда, когда среди людей остынет любовь, люди создадут исключительно антропоцентрические ${ }^{25}$ «философии лжи и апологии лжи» ${ }^{26}$, а религию будут считать «опиум для народа» ${ }^{27}$. Вследствие этого начнутся очень жестокие гонения христиан, ибо те, «кто явно не признает антихриста и не будет носить его знак на себе, не сможет ничего купить, ни продать, не пользоваться никакими правами (см. Откр. 13,16.17)» ${ }^{28}$. Впрочем, царствование Антихриста - по мнению владыки Иустина - будет кратковременным. Ссылаясь на поучения св. Кирилла Иерусалимского, а также на ветхозаветную Книгу Даниила (см. Дан. 7,25) и Откровение св. Иоанна Апостола (см. Откр. 12,14; 11,2; 13,5; $11,3 ; 12,6 ; 12,12)$, сербский богослов утверждает, что период господства лжепророка будет длиться три с половиной года, или сорок два месяца, или тысячу двести шестьдесят дней, или же просто немного времени ${ }^{29}$. К сожалению, архимандрит Иустин не уточняет, сколько же точно будет

\footnotetext{
${ }^{21}$ Ibidem, 76, 78.

${ }^{22}$ См. ibidem, 83.

${ }^{23}$ Cм. ibidem, 83, 85, 98.

${ }^{24}$ Ibidem, 77.

${ }^{25}$ См. ibidem, 91. «По сути, это будет новый вид идолопоклонства, бесстыднейшего идолопоклонства - человекопоклонства». Ibidem, 131.

${ }^{26}$ Ibidem, 98.

${ }^{27}$ CM. ibidem, 91.

${ }^{28}$ Ibidem, 79.

${ }^{29}$ См. ibidem, 79-80.
} 
длиться этот период, когда он наступит, а также, каким образом распознать Антихриста среди многих правителей этого мира. Не уточняет он также будет ли Антихрист фигурой коллективной или же будет действовать в одном лице. Подобно Владимиру Соловьеву, припоминает лишь о том, что, в конечном итоге, каждый человек должен будет сделать фундаментальный, радикальный и бескомпромиссный выбор своей жизни: выбор между Христом и Его полной противоположностью - Антихристом $^{30}$. По своей сути этот выбор касается жизни и смерти.

\section{3. ВТОРОЕ ПРИШЕСТВИЕ ИИСУСА ХРИСТА}

Только Христос является единственным Господом и Спасителем мира. Когда зло в личности и деятельности Антихриста достигнет своего пика, Господь Своим появлением убьет Антихриста и Своим Сиянием искоренит всякое зло на земле ${ }^{31}$. Проповедуя о последних временах этого мира, архимандрит Иустин Попович обращается к эсхатологическим и апокрифическим текстам Святого Писания. Подобно Христу, просит свою паству постоянно бодрствовать, ибо, кроме Отца, никто не знает достоверной даты Парузии, даже Сын Человеческий (см. Мк. 13,33-37; Мт. 24,36-39). В то же время, он обращает внимание на тот факт, что Второе Пришествие Иисуса Христа, как и Его первое пришествие в Тайне Воплощения - это два наиболее важные события в истории Вселенной. «Первое сеяние, второе - жатва; первое показало и дало роду человеческому все Божественные истины и силы для спасения людей от греха, смерти и дьявола, второе явит и обнаружит, как род человеческий этим воспользовался» ${ }^{32}$. Второе Пришествие Христа будет сопровождаться Страшным Судом, которого «никто из людей не избежит», ибо подвергнутся ему «все человеческие существа вместе взятые и каждое по отдельности» ${ }^{33}$. «Тогда обнаружатся не только наши дела, но и все наши мысли, чувства, желания и слова» ${ }^{34}$. Архимандрит Иустин предупреждает, что для грешников

${ }^{30}$ Włodzimierz Sołowjow, „Krótka opowieść o Antychryście”, w: Wybór pism, tłum. Juliusz Zychowicz, Aleksander Hauke-Ligowski (Poznań: Wydawnictwo „W drodze”, 1988), 122-150. Por. Tomáš Špidlík, Myśl rosyjska. Inna wizja człowieka, tłum. Janina Dembska (Warszawa: Wydawnictwo Księży Marianów, 2000), 287-288.

${ }^{31} \mathrm{Cм}$. Попович, Догматика Православной Церкви: эсхатология, 101.

${ }^{32}$ Ibidem, 80.

${ }^{33}$ Ibidem, 125-126.

${ }^{34}$ Ibidem, 127. 
Страшный Суд будет действительно страшным и ужасным, ибо они убедятся в ошибочности своих переубеждений, а также в том, что только в сладчайшем имени Иисус есть спасение от грозной бессмыслицы греха и смерти ${ }^{35}$.

Ссылаясь на теорию рекапитуляции св. Иринея Лионского, сербский богослов немало места посвящает размышлениям о воскрешении человеческого тела, а также об обновлении сотворенной природы (гр. anakefalaiosis; лат. recapitulatio), утверждая, что «воскресение будет состоять в том, что тела всех умерших людей заново соединятся со своими душами и станут духовными и бессмертными» ${ }^{36}$, а «вся драма земли окончится» ${ }^{37}$. «Воскресшие тела - по мнению архимандрита - хотя и будут духовны и бессмертны, но все же не утратят своей сущности, того, что тело делает телом, ибо воскресение не есть создание нового тела, но оживление и преображение ветхого. Своей всемогущей силою Бог воскресит истлевшие и разложившиеся тела. [...] Главное различие между нынешними и будущими воскресшими телами, и их свойствами будет состоять главным образом в том, что воскресшие тела будут бессмертны и духовны, и будут действовать духовным образом. Бессмертие их будет состоять в том, что они не будут иметь возможности умереть, а духовность в том, что они будут жить, как ангелы» ${ }^{38}$.

Если же речь идет об восстановлении природы, то в день Пришествия Господа Иисуса, «вся природа освободится от рабства, греха и смерти, преобразится и заблистает своей первобытной, такой же, как и до падения, безгрешной, бессмертной красотой» ${ }^{39}$. Преподобный Иустин убежден, что вся эта космическая катастрофа закончится преображением мира, а после Страшного Суда земля продолжит свое существование, но это уже будет новая земля и новое небо, в которых будет пребывать новый человек ${ }^{40}$.

К сожалению, рассуждая о наступлении эсхатологических времен и Страшном Суде, архимандрит Иустин Попович очень много внимания приделает злу и его разрушительному действию и очень мало обращает внимание на то, что, Евангелие, по своей сути, является Благой Вестью о безграничной любви Бога к человеку. «Бог и дьявол предстоят ему в такой

\footnotetext{
${ }^{35}$ Cм. ibidem, 128.

${ }^{36}$ Ibidem, 105.

${ }^{37}$ Ibidem, 128. См. Mateusz Oborzyński, „Elementy polemiki antygnostyckiej w teorii rekapitulacji św. Ireneusza z Lyonu”, Bielańskie Studia Teologiczne 3 (2017): 25-41.

${ }^{38}$ Попович, Догматика Православной Церкви: эсхатология, 110.

${ }^{39}$ Ibidem, 115.

${ }^{40}$ См. ibidem, 119. См. Иустин Попович, Философские пропасти, пер. М.Н. Яценко (Москва: Издательский Совет Русской Православной Церкви, 2005), 47.
} 
силе святости и ужаса, что природа, тварь, человек остаются совершенно подавленными, незаметными, ничтожными. Иустин Попович забывает о твари, о ее святости, о ее пределе - который и явлен людям в образе Богорождающей природы - в лице Приснодевы Марии». В связи с этим, «систему Иустина Поповича можно назвать радикальным дуалистическим трансцендентизмом» ${ }^{41}$. Кроме того, сербских богослов не упоминает о притчи о Страшном Суде с 25 раздела Евангелии от Матфея, а также вовсе не концентрируется на радости эсхатологической встречи Церкви со Своим Божественным Женихом. А ведь эта Церковь, которая «всех охристовляет и обогочеловечивает» ${ }^{42}$ с тоской ожидает Его Второго Пришествия.

\section{ЛИТЕРАТУРА}

Misiurek, Jerzy. „Antychryst”. B Encyklopedia Katolicka, red. Feliks Gryglewicz, Romuald Łukaszyk, Zygmunt Sułowski, т. 1, 709-710. Lublin: Towarzystwo Naukowe KUL, 1985.

Oborzyński, Mateusz. „Elementy polemiki antygnostyckiej w teorii rekapitulacji św. Ireneusza z Lyonu". Bielańskie Studia Teologiczne 3 (2017): 25-41.

Romaniuk, Kazimierz. „Antychryst”. B Encyklopedia Katolicka, т. 1, 708-709.

Sołowjow, Włodzimierz. „Krótka opowieść o Antychryście”. B Wybór pism, tłum. Juliusz Zychowicz, Aleksander Hauke-Ligowski. Poznań: Wydawnictwo „W drodze”, 1988.

Špidlík, Tomáš. Myśl rosyjska. Inna wizja człowieka, tłum. Janina Dembska. Warszawa: Wydawnictwo Księży Marianów, 2000.

Špidlík, Tomáš. Życie po śmierci. Maranatha, tłum. Patrycja Mikulska. Kraków: Salwator, 2009.

Зандер, Лев Александрович. „Книга о Достоевском, как введение в православное мировоззрение”. Путь (1927), 8: 149-153 [Zander, Lev Aleksandrovich. „Kniga o Dostoyevskom, kakvvedeniye v pravoslavnoye mirovozzreniye”. Put' (1927), 8: 149-153].

Зенковский, Мефодий. „Понятие человеческой личности в сербской богословской мысли ХХ века". В Труды Перервинской Духовной Семинарии (2013), 9: 23-50 [Zenkovskiy, Mefodiy. „Ponyatiye chelovecheskoylichnosti v serbskoy bogoslovskoy mysli XX veka”. V Trudy Perervinskoy Dukhovnoy Seminarii (2013), 9: 23-50].

Мень, Олександр. Апокаліпсис. Тлумачення Книги Одкровення, перекл. Мирослави Лемик. Львів: Свічадо, 2016 [Men', Oleksandr. Apokalipsis. Tlumachennya Knigi Odkrovennya, perekl. Miroslavi Lemik. L'viv: Svichado, 2016].

Попович, Иустин. „От редакции”. В Догматика Православной Церкви: эсхатология, перевод М.Н. Яценко, 3-5. Москва: Издательский Совет Русской Православной Церкви, 2005 [Popovich, Iustin. „Ot redaktsii”. V Dogmatika Pravoslavnoy Tserkvi: eskhatologiya, perevod M.N. Yatsenko, 3-5. Moskva: Izdatel'skiy Sovet Russkoy Pravoslavnoy Tserkvi, 2005].

41 Л.А. Зандер, „Книга о Достоевском, как введение в православное мировоззрение”, Путь (1927), 8: 152-153. См. Д. Трибушный, „Рецепция понятия «Всеединство» в богословской системе Преподобного Иустина Челийского”, Христианское чтение (2017), 5(76): 74-85.

42 Попович, Догматика Православной Церкви: эсхатология, 123. 
Попович, Иустин. Догматика Православной Церкви: пневматология, перевод М.Н. Яценко, Москва: Издательский Совет Русской Православной Церкви, 2007 [Popovich, Iustin. Dogmatika Pravoslavnoy Tserkvi: pnevmatologiya, perevod M.N. Yatsenko. Moskva: Izdatel'skiy Sovet Russkoy Pravoslavnoy Tserkvi, 2007].

Попович, Иустин. Догматика Православной Церкви: эклесиология, перевод М.Н. Яценко. Москва: Издательский Совет Русской Православной Церкви, 2005 [Popovich, Iustin. Dogmatika Pravoslavnoy Tserkvi: eklesiologiya, perevod M.N. Yatsenko. Moskva: Izdatel'skiy Sovet Russkoy Pravoslavnoy Tserkvi, 2005].

Попович, Иустин. Философские пропасти, пер. М.Н. Яценко. Москва: Издательский Совет Русской Православной Церкви, 2005 [Popovich, Iustin. Filosofskiye propasti, per. M.N. Yatsenko. Moskva: Izdatel'skiy Sovet Russkoy Pravoslavnoy Tserkvi, 2005].

Радованович, Иеромонах. „По страницам богословских трудов архимандрита Иустина (Поповича)”. Журнал Московской Патриархии 4(1999): 30-57 [Radovanovich, Iyeromonakh. „Po stranitsam bogoslovskikh trudov arkhimandrita Iustina (Popovicha)". Zhurnal Moskovskoy Patriarkhii 4 (1999): 30-57].

Rigaux, Béda. „Antychryst”. B Stownik teologii biblijnej, red. Xavier Léon-Dufour, thum. i oprac. Kazimierz Romaniuk (Poznań: Pallotinum, 1994), 52-54.

Трибушный, Димитрий. „Рецепция понятия «Всеединство» в богословской системе Преподобного Иустина Челийского”. Христианское чтение (2017), 5(76): 74-85 [Tribushnyy, Dimitriy. ,Retseptsiya ponyatiya «Vseyedinstvo» v bogoslovskoy sisteme Prepodobnogo Iustina Cheliyskogo". Khristianskoye chteniye (2017), 5(76): 74-85].

\section{НЕТОГРАФИЯ}

Холмогоров, Егор. „Преподобный Иустин (Попович)”. Церковность. Православный интернетальманах 1(1999) [Kholmogorov, Yegor. „Prepodobnyy Iustin (Popovich)”. Tserkovnost'. Pravoslavnyy internet-al'manakh], http://www.romanitas.ru/content/popovich/life.htm (доступ: 10.02.2021).

\section{ПОСЛЕДНИЕ ВРЕМЕНА ЭТОГО МИРА В БОГОСЛОВСКОЙ МЫСЛИ ПРЕПОДОБНОГО ИУСТИНА ПОПОВИЧА}

\section{Р е $з$ ю м е}

Учение о последних временах этого мира преподобного Иустина Поповича концентрируется прежде всего вокруг знаков, возвещающих конец света, к которым относится проповедь Евангелия всем народам, обращение Израиля ко Христу, появление Антихриста, космическая катастрофа, а также небесное знамение креста накануне Второго Пришествия Спасителя. По мнению преподобного Иустина, наиболее трагическим моментом в конце этого мира будет появление Антихриста, в котором все зло достигнет своего апогею. Исходя от Священного Писания, а также трудов Отцов Церкви, архимандрит Иустин рассуждает о воскрешении человеческого тела, а также об анакефалаиосисе всего тварного под главою Христом, кода лишь Бог «будет все во всем» (1 Кор. 15,28). Для архимандрита Иустина самым большим даром Воскресшего Богочеловка естеству человеческому является бессмертие тела и материи.

Ключевые слова: эсхатология; Парузия; Страшный Суд; Антихрист; анакефалаиосис; преподобный Иустин Попович. 


\section{CZASY OSTATECZNE W REFLEKSJI TEOLOGICZNEJ CZCIGODNEGO JUSTINA POPOVICIA}

\section{Streszczenie}

Nauczanie św. Justyna Popovicia o czasach ostatecznych jest skoncentrowane przede wszystkim wokół znaków zapowiadających koniec świata, do których należy głoszenie Ewangelii wszystkim narodom, nawrócenie Izraela do Chrystusa, pojawienie się Antychrysta, katastrofa kosmiczna, a także niebiański znak krzyża w przeddzień powtórnego przyjścia Zbawiciela. Zdaniem św. Justyna Popovicia najtragiczniejszym momentem na końcu tego świata będzie pojawienie się Antychrysta, w którym wszelkie zło osiągnie swój punkt kulminacyjny. W oparciu o Pismo Święte oraz nauczanie Ojców Kościoła, archimandryta Justyn rozmyśla o zmartwychwstaniu ludzkiego ciała, a także rekapitulacji całego stworzenia pod panowaniem Chrystusa, gdy Bóg „będzie wszystkim we wszystkich” (1 Kor 15,28). Według archimandryty Justyna największym darem Zmartwychwstałego Bogoczłowieka dla ludzkości jest nieśmiertelność ciała oraz materii.

Słowa kluczowe: eschatologia; Paruzja; Sąd Ostateczny; Antychryst; rekapitulacja; św. Justyn Popović. 